\title{
Proces socializácie a výchova v škole
}

\author{
Peter Ondrejkovič
}

\begin{abstract}
Abstrakt: Stávanie sa spoločenskou bytostou nie je len otázkou výchovy a vzdelávania, je to proces socializácie, „učenie sa v spoločenských podmienkach“, proces vzniku a vývinu osobnosti vo vzájomnej závislosti od spoločensky sprostredkovaného sociálneho a materiálneho okolia. Teória socializácie v škole musí vysvetlit', ako sa spája reprodukcia spoločenského systému s vývinom osobnosti jednotlivca a súčasne musí vysvetlit', ako môžu spolu fungovat' kritický vývin subjektu a spoločenské zmeny. Významnú súčast' výchovy a vzdelávania predstavuje i utváranie identity žiakov. Bez vzniku identity „môjho ja“ nemožno hovorit ani o autoregulácii.
\end{abstract}

Klúčové slová: socializácia, výchova, vzdelávanie, identita, interakcionalizmus

\section{1 ÚVOD}

Tento príspevok nie je o Durkheimovi, ani o Schützovi, Maslowovi, ani o Parsonsovi. Bude iba nadväzovat' na ich myšlienky, osobitne ma myšlienky Durkheima, ktoré sú po 100 rokoch stále aktuálne. Vo svojich povestných prednáškach o pedagogike v Bordeaux (1896) si postavil otázku, ako je možné, že „...indivíduum popritom, čo sa stáva čoraz autonómnejšou bytostou, sa súčasne stáva čoraz viac závislou na spoločnosti?" (Durkheim, 1977, 78). Stávanie sa spoločenskou bytostou nie je len otázkou výchovy a vzdelávania, je to proces socializácie, ktorý na Slovensku Anton Jurovský ešte v r. 1973 - 1974 nazval „učenie sa v spoločenských podmienkach“. K otázkam socializácie sa vraciame vlastne neustále aj v podobe nadobúdania sociálneho a kultúrneho kapitálu. Socializácia je jedným z "mechanizmov" spoločnosti, napriek postmoderným genealogickým a antiuniverzalistickým výhradám ${ }^{1}$ (predovšetkým $v$ sociológii ${ }^{2}$ ), ale vraciame sa osobitne i k otázkam reciprocity vztahov mládeže a konkrétnych mladých ludí a súčasnej spoločnosti. Najmä postmoderné teórie, teórie rizikovej spoločnosti, $\mathrm{i}$ celá interpretatívna paradigma $v$ sociológii výchovy aj $v$ sociálnej práci upozorňujú tak na opustenost' mládeže ${ }^{3}$, ako i na jej ponechávanie svojmu osudu v nechránenom priestore spoločnosti, bez relatívne stabilnejších hodnôt a noriem. Práve pedagogika, osobitne sociálna pedagogika sa nezaobídu bez reflexie celoživotného procesu človeka, ktorým je stávanie sa sociálnou bytostou, počínajúc narodením, až do staroby a ukončením života. Socializácia je však aj

1 Presvedčenie, že neexistuje jednotné morálne univerzum, platí iba pluralita práva a hodnotový relativizmus.

2 V rozpore s kontinuitou vývoja spoločnosti sú Foucaultovo antiuniverzalistické názory na diskontinuitu dejín, názory na „skutočnú“ históriu, ktorá nie je nominalistická, a je udalostná. Foucault pokladá za nevyhnutné hladat' pri každej udalosti resp. výpovedi o nej špecifické podmienky jej vzniku, existencie, transformácie a rozptylu. Súhrn týchto podmienok nazýva epistémou. Foucaultova archeológia a genealógia dospievajú k principiálnej nemožnosti usporadúvat' a hierarchizovat' dejiny, pričom sa otvorene stavia na stranu diskontinuitných, lokálnych, diskvalifikovaných a nelegitímnych foriem vedenia (Foucault, 1969; Buraj, 2000).

3 Osobitne inšpirujúce sú myšlienky Alfréda Schütza o „zabudnutom človeku“ v sociálnych vedách, ako i fenomenologický výklad sociality a sociálna, ktorých základ spočíva vo vztáahu „ja“ k „ty“, konštitúcii zmyslu alter ego (druhé ja), kde vcítenie sa a Fremdverstehen (rozumenie druhému) možno pokladat' za súčast' priebehu procesu socializácie. Podrobnejšie pozri aj Geertz (1973). „Schützovská sociálna veda“ sa tak stáva inšpiromatom i v teóriách socializácie a čaká na svoje podrobnejšie rozpracovanie, ktorého sa čiastočne dočkala v skvelej práci Dilbar Alijevovej Príspevok Alfréda Schütza k sociologickej teórii. 
procesom vzniku a vývinu osobnosti vo vzájomnej závislosti od spoločensky sprostredkovaného sociálneho a materiálneho okolia (Ondrejkovič, 1997, 53 - 54). Ked'opomenieme Foucaultovo búranie zaužívaných predstáv o identite, chápaní vlastného "ja“", ktoré sú skôr spoločenskou konštrukciou reality, než nazeraním na jednotlivca ako na autonómny karteziánsky subjekt, znamená to teda, že socializácia bezprostredne súvisí s celým komplexom životných podmienok ako celkom, ktoré majú vplyv na vývin subjektu. $V$ tejto súvislosti už jeden z velikánov psychológie 20. storočia Maslow upozornil na to, že tak existenciálni filozofi, ako aj freudovci, existenciálni terapeuti, rogersovci a psychológovia osobného rastu „....príliš psychologizujú a primálo sociologizujú. Znamená to, že nedostatočne zdôrazňujú vo svojom systematickom myslení vel'kú silu autonómnych sociálnych a environmentálnych determinánt ...mimo jednotlivca,... ich bezmocnosti pri týchto vplyvoch“ (Maslow, 2001, 44). Mladý človek - aktér procesu socializácie, sa ocitáva vlastne v štruktúre sociálnej reality $v$ úlohe cudzinca. Sociálna realita, hodnoty, normy, sociálne roly, postoje a vzorce správania, príp. kultúra sa ešte nestali integrálnou súčastou jeho biografie. V zmysle Schützovej teórie Lebensweltu by sme mohli povedat', že je „človekom bez histórie“ (Schütz, 1971, 96). Preto nielenže nie je schopný integrovat' svoju typizáciu do koherentného systému referenčnej skupiny, do ktorej by najradšej (a čím skôr) patril, ale nemôže sa spolahnút ani na očakávania zo strany príslušnej skupiny, v dôsledku nedostatku svojich predchádzajúcich sociálnych skúseností (stock of knowledge at hand, Wissensvorrat). Jeho správanie sa stáva skôr dobrodružstvom, príp. experimentom. Táto skutočnost' iba dokazuje význam sociálnych determinánt, ich nadosobnú silu, ale aj bezmocnost' človeka a súčasne aj to, akú vel'kú pravdu má Maslow, ked' zdôrazňuje vel'kost' omylov, ktorých sa dopúštame pri jednostrannom psychologizovaní.

Socializácia je i procesom, prostredníctvom ktorého sa subjekt stáva schopným sociálneho (morálneho) konania. Teda konania, v ktorom už regulujú jeho správanie isté hodnoty, normy a vzorce správania. Ide o správanie, ktoré sa manifestuje $v$ jeho vztáahoch $s$ jednotlivcami, spoločenskými skupinami i celou spoločnost'ou. Je to správanie, v ktorom dokáže rozlišovat' dobro a zlo, ako i následky svojho správania. Ked'si mládež v procese socializácie osvojuje také hodnoty a normy, prostredníctvom ktorých nie je schopná sociálneho (morálneho) správania, dochádza neraz k odhal'ovaniu súčasného neradostného stavu spoločnosti. Tento stav spočíva i podla mnohých sociológov a filozofov v kríze hodnôt a noriem, v nenaplnenej l'udskej túžbe po transcendencii, spočiva v pocitoch životnej úzkosti, ktorá vyplýva z nestability všetkého okolo nás, ale aj v nevyhnutnosti ustavičnej vol'by, ktorej tiaž človek nedokáže uniest'. Podl'a mnohých je to spoločnost', ktorá technologickou racionalitou iba zakrýva nudu a prázdnotu súčasného človeka, zbaveného viery, naplneného pocitmi bezmocnosti, ale $\mathrm{i}$ viny, spoločnost', v ktorej vyhasínajú citové väzby k blízkym, vyhasínajú aj vyššie emócie, ubúda emocionálna inteligencia „Rôzne veky mali svoje vzory: svätec, hrdina, gentleman, rytier, mystik a pod." Toho všetkého sa naša doba vzdala. Miesto toho zostal „prispôsobený človek bez problémov, vel'mi bledá a pochybná náhrada" - uvádza Maslow v jednej zo svojich početných publikácií (Maslow, 2001). Iba existencionalistické štúdium autentického človeka a autentického žitia pomáha vrhnút túto všeobecnú faloš, toto žitie ilúziou a strachom do ostrého svetla, v ktorom sa jasne javí ako choroba, hoci je masovo rozšírená (Maslow, 2001, s. 47). Ešte vážnejší je však problém, ked' si v procese socializácie mládež osvojuje tieto "jednorozmerné“ hodnoty a normy bez toho, aby ich podrobovala kritickej reflexii, oddáva sa priemernosti, „l'ahkosti bytia“, alebo násiliu, ktorým často rieši svoj protest a neschopnost́ vlastnej autentickej existencie (Heidegger, Mracuse, Sartre a i.). Je to stav, kedy to, čo nazývame „normálnym“, je v skutočnosti maslowovská „psychopatológia priemeru“, tak široko rozšírená, že si to bežne ani neuvedomujeme.

Udalosti v septembri 2001, ktoré súviseli s teroristickým náletom a zničením Word Trade Center obchodného centra $v$ New Yorku, nás na jednej strane konfrontovali $s$ narastaním násilia na tejto planéte, ktoré sa stáva svetovým globálnym fenoménom, no súčasne znova s neobyčajnou naliehavostou otvorili otázku liberálnych hodnôt, významu blahobytu, „konzumnej kultúry“ a ich pomeru k tradíciám, religiozite a duchovnému životu a hodnotám stredných spoločenských vrstiev, pre ktorých je príznačná multikultúrna tolerancia, teda k hodnotám, ktoré zohrávajú v procese socializácie klúčové postavenie. Objavila sa otázka, čo máme vlastne obhajovat', aké hodnoty „nášho modelu“ 
spoločnosti a spôsobu života vo vzt́ahu k islamistickým teroristom? „Čo je dôležité pre l'udí medzi Aténami a Lisabonom, medzi Berlínom a New Yorkom, okrem práce, chleba, pôžitku a komfortu?" pýta sa časopis Der Spiegel v článku nazvanom Viera neveriacich, alebo aké sú hodnoty Západu? (Mohr, Saltzwedel, Schmitter \& Schreiber, 2001, s. 56). Je to demokracia? Zaiste. Ale aj viera v Boha? A pre tých, ktorí ho hladajú alebo pochybujú o jeho existencii, nezostáva už skutočne nič, len blahobyt, peniaze, majetok a duchovné prázdno? Nestávajú sa tak peniaze jedinou vierou, čo môže byt' vo svojich dôsledkoch nebezpečnejšie ako náboženský fundamentalizmus? - pýta sa známy spisovatel' Peter Handke na svetovom diskusnom fóre v Berlíne.

Socializácia je i procesom konštrukcie reality prostredníctvom spoločensky sprostredkovaného sociálneho a materiálneho okolia, ktorú si jednotlivec osvojuje v podobe internalizovaných hodnôt, noriem a porozumenia kultúre, a ktoré štrukturujú jeho konanie. Toto konanie iste ovplyvňuje nemálo faktorov, nazdávame sa, že výchova a vzdelávanie významne ovplyvňujú konanie, najmä ako súčasti sociálnych nerovností (pochopitel'ne podmienených aj inými faktormi), čo podl'a teórie Bella (1985) predstavuje neustále narastajúci trend. Otázkou je, aký je ten svet života (Lebenswelt), ktorého hodnoty a normy si človek osvojuje: tu má sociológia vel'ký dlh, syntetizovat' svoje čiastkové poznatky do podoby celostného obrazu ako zrkadla, ktoré by mohla nastavit' spoločnosti. Zastávame názor, podla ktorého štruktúru sociálneho konania silne poznačujú aj intergeneračné vzorce mobility, ovplyvnené jestvujúcim systémom výchovy a vzdelávania. Mohli by sme sa preto pýtat', do akej miery môžeme vzdelanie a vzdelávanie aplikovat́ pre vysvetlenie sociálneho konania.

Za činitele, ktoré sprostredkovávajú tento zložitý proces socializácie budeme pokladat́ tzv. socializačné činitele (tabul'ka 1), z ktorých nie všetky sa podielajú rovnakou intenzitou a rovnakým spôsobom na procese socializácie.

Tabul'ka 1

Socializačné činitele

ROVINA

PRÍKLADY KOMPONENTOV

1. SPOLOČNOSŤ AKO CELOK Štruktúry ekonomické, politické, kultúrne, príp. etnické;

2. INŠTITÚCIE Pracovisko, masmédiá, školy, univerzity, armáda, cirkev;

3. INTERAKCIE A ČINNOSTI Vzt'ahy rodičia - dieta, školské vyučovanie, komunikácie medzi rovesníkmi, priatel'mi, príbuznými;

4. SUBJEKT

Skúsenostné vzory, postoje, vedomosti a poznatky, emocionálne štruktúry, kognitívne schopnosti ap.

Narastajúce odhierarchizovanie a klesajúca diferenciácia vztahov v rodine a narastajúce vzdelávacie a mobilitné nároky spôsobujú čoraz väčšiu priepustnost', ba prekrývanie medzi jednotlivými segmentmi socializácie. Popri rodine, ktorá od čias S. Freuda a T. Parsonsa stála v centre vysvetl'ovania genézy osobnosti, nadobúdajú čoraz väčší význam škola a pracovisko, ako i neformálne zoskupenia, osobitne rovesnícke skupiny, predovšetkým mládeže. Celkom mimoriadny význam nadobúda svojím socializačným vplyvom neustále expandujúci zábavný priemysel, sprostredkujúci obraz sveta, ktorý často nadobúda podobu virtuálnej reality. Najväčšiu zásluhu na tom majú najmä masovokomunikačné prostriedky, vplyvom ktorých sa tradičné vzorce správania, roly v rodine a povolaní stávajú čoraz hmlistejšími a nejasnejšími.

Nové prúdy v sociológii, psychológii, sociálnej pedagogike, sociálnej antropológii a filozofii vytvárajú čoraz silnejší tlak, ktorý vyústúuje do snahy skúmat' spoločnost' i človeka v nej, v jeho skutočnom, sociálnom a kultúrnom prostredí. Toto skúmanie ale nemôže vychádzat' z mylnej predstavy, podl'a ktorej jediným, čo môže byt' podrobené empirickému výskumu je to, čo je opakovatel'né, meratel'né, medzi čím jestvujú viac či menej kauzálne vztahy, udalosti, ktoré sú spájané množstvom zákonov 
a zákonitostí, čo je možné napriek ich zložitosti a komplexnosti preskúmat', a to spôsobom, ktorý sa používa $v$ prírodných, osobitne vo fyzikálnych vedách, $v$ anorganickej chémii a Newtonovskej mechanike. $V$ takomto postupe sa skúmanie sústred'uje na matematické zákony, štatistické korelácie a kontingencie, najmä medzi situačným podnetom a situačnou odpoved'ou. Všetko, čo predstavuje komplikácie, sa zo skúmania preto spravidla následne vylučuje ako interferujúce s úsilím empirickej vedy. Je teda otázkou, aké miesto zaujíma biologická a telesná determinovanost' človeka v procese socializácie, aká je sila diskurzu (pri všetkej diverzite jeho definícií) ${ }^{4}$ ako vztáahu medzi udalost́ami a ich významom $v$ procese socializácie. Toto konštatovanie znamená priam výzvu $\mathrm{k}$ vzd'alovaniu sa spoločenských vied od metodológie prírodných vied, $\mathrm{k}$ aplikácii iných výskumných postupov, príznačných pre prírodné vedy, $v$ ktorých spravidla prevláda jednostranná kauzalita. Mohli by sme povedat', že sociálne vedy by mali prestat' napodobňovat' metodológiu prírodných vied. Toto vzd'al'ovanie sa v metódach však neznamená vzd'al'ovanie sa od prírodných vied, a teda nemusí znamenat ani narastanie priepasti medzi nimi. $V$ skúmaní socializačných procesov by to malo znamenat pokus o odhal'ovanie nedeterministických pravidelností, dialektických súvislostí, teda diskurzu v danom spoločenstve, komunite. Tu bude nevyhnutné vychádzat' z toho, že ak sa význam sociálneho prostredia vytvára v každodennom diskurze a tento význam nie je produktom kontinuálneho vývoja spoločenskej substancie, potom možno proces socializácie výskumne postihovat' p ri a mo, t. j. nie iba prostredníctvom hypoteticko-deduktívnych modelov a testovaním deduktívne odvodených hypotéz (z týchto modelov), čo je charakteristické pre kvantitatívne metódy výskumu. Výskum socializácie bude potom môct' byt' štúdiom utvárania siete významov, ktoré si človek sám usporadúva (Geertz, 1973; Plichtová 2001, s. 22) a to tak priamo, ako aj prostredníctvom odvodzovania a následne testovania hypotéz. Budeme preto socializáciu charakterizovat' ako proces, ktorý sa významove odohráva v troch rovinách:

Školy ako inštitúcie sú poverované pedagogickými úlohami, ktoré všeobecne nazývame výchovnovzdelávacím systémom. Tu neprebieha socializácia akoby pomimo, je doslova plánovaná ako hlavné poslanie - príprava mladého človeka pre život v spoločnosti. Výchovnovzdelávacie systémy prešli za obdobie cca 200 rokov svojej existencie zložitým vývinom, až dospeli do štádia, kedy sa stali vysoko komplexnými, významne ovplyvňujúcimi, ba neraz až podmieňujúcimi životné dráhy a perspektívy človeka. Škola sa stala jednou z najväčších verejných inštitúcií spoločnosti. Ako spoločenská inštitúcia je charakteristická jednotou noriem, formalizovaných rolových očakávaní a materiálnych podmienok. Školy zamestnávajú špeciálne pripravených pracovníkov, ktorí vykonávajú pedagogickú prácu ako svoje povolanie. Sú to učitelia a vychovávatelia, ktorí ako pracovníci špecializovanej spoločenskej inštitúcie so socializačnou funkciou majú osobitné miesto vo vztáahu k štátu, spoločnosti, jej normám a hodnotám, kedže pripravujú deti a mládež pre život v spoločnosti. Ich povinnostou je okrem iného orientovat' svoje výchovnovzdelávacie pôsobenie tak metodicky, ako aj obsahovo na spoločenské ciele, formulované v učebných plánoch. Možno povedat', že škola ako spoločenská inštitúcia má pedagogickú prácu a s ňou súvisiace úlohy zabudovanú vo všetkých svojich organizačných štruktúrach, čo býva nezriedka terčom kritiky, ako byrokratické určovanie úloh a poslania školy zvonka. Ked' si však uvedomíme, že len na území Slovenskej republiky denne navšte -

4 Diskurz v užšom slova zmysle (nie striktne vo význame, ako ho používa Foucault ) býva chápaný ako konkrétne vedenie. Ricoeur prízvukuje, že diskurz je vztahom medzi udalost'ou a významom. Je typický pre určitú epistému, t. j. epochu, pre ktorú je príznačné určité vedenie, vrátane postupov a súboru pravidiel, ktoré sú v tejto epoche „akoby“ predpisované autorom diel, ktorí v danej epoche pôsobia. Vo význame, v akom diskurz používa Foucault, nemáme do činenia iba s d’alším slovom, ale činom, praktikou, ktoré vytvárajú nové vzt́ahy, vrátane vzt́ahov mocenských a nové druhy vedenia. Diskurz jestvuje vo vnútri inštitúcií a sociálnych skupín, spoluvytvára ich a je viazaný špeciálnymi druhmi vedenia. Pripomenieme, že diskurzy môžeme rozdelit' podla jednotlivých sociálnych sfér (napr. mediálny, politický, pedagogický ako vedecký) alebo na základe užšie špecifikovanej témy (napr. diskurz školského úspechu, autority učitel'a u M. Strouhala a i.). V rámci diskurzov vzhl'adom na ideológiu, ktorú reprezentujú, môžeme rozlišit' diskurzy dominantné a alternatívne (napr. pedagogika a edukológia). Tiež je možné triedit' diskurzy na základe rovín: diskurzy a metadiskurzy (t. j. diskurzy o diskurzoch, diskurzy „druhého rádu“). 
vuje materské, základné a stredné školy cca 1174000 žiakov, ktorých vyučuje cca 95000 učitel'ov a výchovných pracovníkov, je celkom jednoznačné, že kontinuálne výchovnovzdelávacie činnosti takéhoto vel'kého rozsahu nemôžu zostat' bez rozsiahleho organizačného zabezpečenia, vrátane príslušného nepedagogického aparátu. To súčasne umožňuje v praxi spoločenskú kontrolu a politické ovplyvňovanie ${ }^{5}$.

Pozrime sa teraz na niekol'ko otázok. Prvú z nich by sme mohli formulovat' nasledovne: Aká forma riadeného a normovaného ovplyvňovania osobnosti sa v škole uskutočňuje naozaj? Možno pritom zaznamenat' rozdiely v závislosti na rôznych formách školského vzdelávania? Uvedené otázky sa týkajú roviny interakcie a osobnosti.

Ďalej by sme sa mohli pýtat', aké sú väzby medzi inštitucionalizovaným procesom socializácie, ktorého predstavitel'om je škola a požiadavkami, ktoré kladie spoločenský systém na proces socializácie. Takto stavané otázky predstavujú funkcionalistickú rovinu našich úvah.

Na uvedené skupiny problémov by mala dat' odpoved' teória socializácie v škole. Musí vysvetlit', ako sa spája reprodukcia spoločenského systému s vývinom osobnosti jednotlivca a súčasne musí vysvetlit, ako môžu spolu fungovat' kritický vývin subjektu a spoločenské zmeny ${ }^{6}$.

\section{NÁVŠTEVNÍK ŠKOLY (ŽIAK, ŠTUDENT) AKO NOSIČ ROL}

Z hl'adiska funkcionalisticko-štrukturálnej teórie zohráva proces socializácie stabilizačnú funkciu v spoločnosti. Dospievajúca mladá generácia sa má stat' životaschopnou v spoločnosti tým, že preberie roly, ktoré jej spoločnost' prisudzuje. Pre prípad, že sa tak v škole nestane, k osvojeniu si rol nedôjde a dôjde k odchýlke voči očakávanému správaniu, nastupujú mechanizmy sociálnej kontroly, akými sú napr. orgány starostlivosti o mládež, polícia, súdnictvo a pod. Podla Mayntzovej, ked'že socializácia a sociálna kontrola podmieňujú cestu $\mathrm{k}$ integrácii a stabilizácii sociálneho systému, socializácia a sociálna kontrola sa stávajú základnými funkcionálnymi procesmi. (Podla Parsonsa dokonca celá socializácia spočíva v „získavaní takej orientácie, ktorá je pre uspokojivé rolové konanie žiaduca“.) Ciel'om procesu socializácie sa tak stáva kompetentné a stabilizujúce rolové správanie. Súčasne sa stávajú sociálne vzorce rolového správania komunikatívnym prostredím, v ktorom sa socializácia uskutočňuje. Kým špecifické formy rolového správania ( $v$ zmysle techník správania a konania) sa žiaci v škole l'ahko naučia, a tým získajú schopnost' ich aplikácie v konkrétnych situáciách, všeobecné orientácie správania sa musia zakotvovat' v osobnosti hlbšie. Schopnost' rolového správania sa teda získava v procese socializácie predovšetkým osvojovaním všeobecnejšej, pre mnohé roly dôležitejšej základnej orientácie. Parsons hovorí v tejto súvislosti o hodnotových vzoroch ako o univerzalistickej orientácii. $\vee$ tom spočiva podl'a Parsonsa relatívna stabilita hodnotového systému spoločnosti. Naproti tomu v rodine a d'alších súkromných kontextoch prevláda skôr opačná hodnotová orientácia - ovel'a afektívnejšie sfarbená, menej stála a taká, v ktorej je príznačné, že nestojí v jej popredí princíp výkonnosti. Takúto hodnotovú orientáciu označuje Parsons ako partikularistickú.

5 Otázkam apolitickosti školy a politických vplyvov na výchovu a vzdelávanie sa venovalo nemálo času a priestoru v období po roku 1989. Autori najrôznejších úvah podliehali ilúziám, podla ktorých je možné výchovnovzdelávacie inštitúcie spoločnosti „uchránit“ spod politických vplyvov (napr. staršie výsledky práce komisie známe ako Duch školy, In: Jednotná škola, 3, 1990, kriticky k tomu pozri Ondrejkovič, P. (1990). Pripomienky k modernizácii čs. školstva a k návrhu všeobecných zásad budúceho čs. školstva Duch školy. Pedagogická revue, 2, 150 - 155). Ovel'a triezvejšie z hl'adiska systémového riešia otázku vztáta výchovnovzdelávacej sústavy a spoločnosti, vrátane politických vplyvov autori projektu Konštantín (Projekt Konštantín, MŠMŠ SR, Bratislava, 1994 a novšie). V nemeckej literatúre sú z tejto oblasti známe viaceré práce H. G. Rolffa, z posledných najmä Rolff, H. G. (1992). Die Schule als besondere soziale Organisation, In: Zeitschrift für Sozialisationsforschung und Erziehungssoziologie, 4, $306-324$. Z najnovších slovenských pokusov pozri práce Kaščáka a Pupalu.

6 Otázkami teórií socializácie v sociológii výchovy sa zaoberá Ondrejkovič (2004), Strouhal (2010), Prokop (1998) a i. 
Z hladiska socializácie možno nastolit' otázku, ako sa môže stat', že dieta, ktoré vyrastá v partikularistických hodnotách rodiny si úspešne dokáže osvojit' univerzalistické hodnoty spoločnosti?

$\mathrm{Na}$ uvedených teoretických základoch spočívajú štrukturálno-funkcionalistické teórie školy ako socializačnej inštancie. Najčastejšie sa objavujú v anglickej a americkej literatúre, počínajúc 40-tymi rokmi tohto storočia. V r. 1959 uverejňuje Parsons svoju „Školskú triedu ako sociálny systém“, ktorá je považovaná za klasiku teórie školskej socializácie. Parsons sa v nej pýta, akú funkciu plní škola $v$ americkej spoločnosti. Vychádza z priemyselnej spoločnosti, ktorá je organizovaná na základe del'by práce. Jej kultúrny systém je určený prostredníctvom univerzalistickej hodnotovej orientácie. $V$ tejto spoločnosti jestvuje vybudovaný verejný vzdelávací systém, ktorého jadrom je inštitúcia školy. Školu povinne navštevujú všetci v období detstva a dospievania. Centrálnym miestom školskej socializácie je trieda. Súčasne s analýzou štruktúry školy ju charakterizuje ako subsystém spoločenského supersystému. Táto štruktúra je východiskom jeho funkcionálnej analýzy. Jeho záujem spočíva v dokazovaní príspevku školy pri integrácii dospievajúcich do spoločnosti, a tým aj príspevku školy k zvyšovaniu stability systému. Parsons identifikuje pritom dve funkcie školy vo vyspelej spoločnosti: socializácia a selekcia.

Socializačná funkcia školy spočiva v zvnútornení všeobecných rolových očakávaní. Škola má i úlohu rozdel'ovat' dospievajúcich na rozličné zamestnanecké (povolanecké) pozície. Má uskutočňovat' selekciu l'udských zdrojov adekvátne systému rol dospelých. Táto funkcia býva označovaná ako alokačná alebo selekčná funkcia školy. Obe funkcie sú komplementárne, ktoré v každodennom živote školy nemožno často od seba ani oddelit'. Analýzou interných procesov, prebiehajúcich $v$ škole, dospieva Parsons k názoru, podla ktorého je jednotkou sociálneho systému v škole trieda. Učitelia a žiaci tvoria podsystémy sociálneho systému triedy. Zdôrazňuje rozdiel medzi spoločenskou rolou učitel'ky $v$ škole a matky v rodine. Školský rok je dostatočne dlhý na to, aby sa vybudovali vztahy medzi žiakmi a jednotlivými učitel'mi. Nie však dost' dlhý na to, aby došlo ku kryštalizácii vyslovene partikulárneho vztahu. Žiak si tak osvojuje (internalizuje) skôr svoj vztáah k role učitela, ako k jeho individuálnej osobnosti, na rozdiel od osvojovania si vztahu dieta - rodič v rodine, kde dochádza k osvojeniu si vztahahu k individuálnej osobnosti rodiča.

Tento proces socializácie ako zvnútornenie rol je spojený takmer od prvých dní pobytu v škole so systematickým a kontinuálnym hodnotením výkonu žiaka, ktorý podáva v škole. Učitelia známkujú a hodnotia, chvália a kritizujú, odmeňujú a trestajú. Tento proces hodnotenia vedie k vnútornej diferenciácii v školskej triede na dobrých a menej dobrých žiakov. Týmto spôsobom sa žiaci učia, ako je možné získat v skupine status a ako je možné ho obhajovat'. Takáto diferenciácia je nevyhnutná, lebo škola je aj inštitúcia so selektívnou funkciou a potrebuje tvorit selekčnú bázu pre pridel'ovanie budúceho spoločenského statusu.

Parsonsovu štrukturálno-funkcionalistickú socializačnú teóriu podrobili masívnej kritike mnohí autori. Jeho teória však bola nielen kritizovaná, ale súčasne aj d'alej rozvíjaná (Fend 1973; Dreeben 1980). V súčasnosti najmä Jeffrey Alexander (2008), profesor sociológie na Yale University, sa v teóriách neofunkcionalizmu pokúša deficity vytýkané Parsonsovi kompenzovat' nadväzovaním na iných klasikov, ako napr. na Richarda Müncha, ako aj stavaním nových otázok. Analytický postup, ktorý aplikoval, je vhodný tak pre mikro- ako aj pre sociálne makroprocesy (personality, cultural system and social system = action, t. j. interpretation/strategization). Nie je tažké u Alexandra rozoznat' 3 systémy, s ktorými pracuje i Parsons (osobnost', kultúrny a sociálny systém). No kým v Parsonsovom štrukturálnom funkcionalizme napr. žiak ako aktér je celkom $v$ pozadí, Alexander prekonáva dichotómiu mikroa makroroviny. Jeho nespornou zásluhou je úsilie problémy nielen vysvetl'ovat', ale aj im porozumiet" ${ }^{7}$.

7 Podrobnejšie pozri o tom Ondrejkovič, P., Majerčíková, J. 2012. 


\section{SOCIALIZÁCIA V ŠKOLE Z POHL’ADU TEÓRIE INTERAKCIE}

V škole nejde vždy iba o výchovu a vzdelávanie, ale súčasne aj o spoločenskú reprodukciu, o výber a selekciu, orientáciu správania. Už štrukturálno-funkcionálna teória socializácie ukázala na to, aký silný je vplyv spoločnosti, aké významné sú jej požiadavky. Pritom jej tažisko spočíva v analýze vztahohov medzi systémami rol a globálnou spoločnostou. Analýza individuálnych foriem správania zostávala skôr v pozadí.

Pri teóriách socializácie z pohl'adu interakcie je tažisko položené inde. Vztahy medzi inštitúciami a globálnou spoločnostou sa síce pokladajú za významné, ale nie sú v centre pozornosti. Táto sa koncentruje ovel'a viac na mikrosociálnu oblast', a síce na interakciu medzi subjektmi. Kým štrukturálnofunkcionalistické teórie nazerajú na školu z perspektívy diváka zvonka, interakcionistické teórie analyzujú problémy socializácie $v$ škole ako zúčastnení. Znamená to, že východiskom sa stáva nie funkcia školy v globálnej spoločnosti, ale každodenné interakcie medzi žiakmi a učitel'mi. Analyzuje sa proces tvorby identity a škola ako inštitúcia je podrobovaná kritike. Osobitné miesto zaujíma pritom symbolický interakcionizmus Georga Herberta Meada (1863 - 1931) a Ervína Goffmana (v publikáciách r. 1967 až 1971). V Spolkovej republike Nemecko sa stretávame s takýmito teóriami koncom 60-tych rokov u J. Habermasa, Krappmanna, Mollenhauera a Brumlika, ktorí rozvíjajú interakcionistické koncepcie i v pedagogike.

Symbolický interakcionizmus v zásade sleduje proces komunikácie medzi subjektmi ako spoločenský proces, v ktorom sa vyvíja identita. Najvýznamnejšie sú pritom dve skutočnosti:

1. jednotlivec disponuje spoločným systémom symbolov (reč) ako ostatní, čo umožňuje vzájomné dorozumievanie sa (úmyselne sa na tomto mieste vyhýbame použitiu termínu komunikácie alebo interakcie, nakol'ko nie je jednoznačne jasné, či ich možno používat' ako identické kategórie, resp. aký je rozdiel medzi nimi);

2. jednotlivec je konfrontovaný $s$ očakávaním stabilizovaného správania, ktoré je naňho nasmerované zo strany toho, s kým sa dorozumieva.

Základným pojmom týchto teórií je interakcia. Znamená vzájomné branie zretel'a aktérov prostredníctvom očakávaného správania vo vlastnom správaní. Termín interakcia je súčasne jedným z ústredných pojmov súčasnej sociológie. Je základom nadviazania sociálneho kontaktu. Vo všeobecnosti možno povedat', že nikto sa nemôže vzdat' minimálne všeobecnej interakcie, lebo sa vystavuje nebezpečenstvu, že si nedokáže vybudovat' vlastnú identitu.

\section{ŠKOLSKÁ SOCIALIZÁCIA A JEJ ŠTRUKTÚRA}

V škole sa uskutočňuje komunikácia zámerne, pravidelne a dlhodobo. Jej obsah a formy sú $v$ značnej miere dopredu inštitucionálne stanovené. $V$ tomto zmysle je aj značne obmedzená možnost' ich podstatnejšieho ovplyvnenia zo strany účastníkov, osobitne žiakov. Tak napríklad nie je možné sa vzájomne dohodnút na neúčasti na vyučovaní, na inej klasifikácii a pod. To, čo nazýva Habermas rigiditou, represívnostou a sociálnou kontrolou, to v procese školskej komunikácie zohráva významnú úlohu. Dôsledkom uvedeného charakteru komunikačného procesu $v$ škole je ovel'a väčši počet „deviantov“ medzi školákmi, ako by sme sa nazdávali.

Interakcionistické analýzy inštitúcie vychádzajú z vnútorného pohladu ich samotných účastníkov. Treba odpovedat' na otázku, ako vychádza v ústrety inštitucionálny aparát aktérom interakcie v inštitúcii (škole). Čo sa v škole ako inštitúcii umožňuje, čo sa vyžaduje a čo sa vynucuje? Ak posudzujeme dianie $v$ škole z tejto perspektívy, treba poukázat' na to, že komunikácia sa uskutočňuje prevažne formalizovaným spôsobom vyučovania. Ked'že škola je zameraná predovšetkým na sprostredkovávanie poznatkov, zručností a prípravy na konanie (napr. v určitej profesii), zaujíma $v$ škole vyučovanie dominantné postavenie. Zaberá najviac času počas prítomnosti žiaka (študenta) v škole a v porovnaní s ostatnými aktivitami je vyučovanie považované za najdôležitejšie. Komunikácia vo vyučovaní je 
poznačená z interakcionistického hladiska niekol'kými dominantnými a pritom inštitucionálne danými znakmi. Sú to:
a. hierarchia
b. donucovanie
c. výkony
d. konkurencia.

Účast' na vyučovaní nie je dobrovol'ná ani pre žiakov (študentov), ani pre vyučujúcich. Pre žiakov napríklad platí aj školopovinnost' a s ňou spojená možnost' použitia sankcií zo strany inštitúcií. Žiak je tak nútený zúčastňovat' sa na vyučovaní aj vtedy, ak o to vôbec subjektívne nemá záujem. Práve z tejto pozície pracovníka školy ako donucovacej inštitúcie má učitel' oproti žiakovi neporovnatel'ne vyššiu definičnú moc - učitelia môžu presadit' svoju interpretáciu príslušnej roly a výklad významu konkrétnej situácie, môžu udel'ovat' príkazy, ktorých neplnenie sa sankcionuje (napr. nevykonaná domáca úloha). V úzkej spojitosti s tým je tu na druhej strane ekonomika komunikácie - treba postupovat tak, aby učitel' dokázal v predpísanom vymedzenom časovom limite „prebrat' látku“ (učivo). Konanie žiakov (študentov), ktoré nie je zamerané na zvládnutie učiva, je považované spravidla takmer vždy za neželatel'né, takže vyučujúci sa všeobecne usiluje takémuto správaniu zabránit', alebo ho potlačit'. Učitel'om pripadá úloha predkladat' žiakom ako svojim interakčným partnerom inštitucionálne definované požiadavky a v nutných prípadoch ich presadzovat'. Podla teórie interakcie žiaci majú za týchto podmienok len obmedzené možnosti prichádzat' s vlastnou interpretáciou svojej roly a s vlastnou predstavou utvárania svojej identity.

V interakcionistických analýzach sa poukazuje na to, že "vyučovacia“ komunikácia je v zásade orientovaná na princíp podávania výkonu, lebo vyučovací proces je „....prevažne ciel'ová orientácia, ktorá je podriadená formálnemu spôsobu výkonov žiakov, známky a vysvedčenia ovládajú školskú scenériu" (Holtappels, 1987, s. 19). Väčšina poznatkov, ktoré si žiaci osvojujú, tak stráca čiastočne znaky individuálneho prínosu a výkonu, nakol'ko povinnost' osvojit' si tieto poznatky je striktne vymedzená v učebných plánoch a ich skutočné ovládanie a reprodukovanie platia v kontexte školy ako školský výkon. Učitelia disponujú inštitucionálne zakotvenými mechanizmami, ktorými aj skutočne dokážu presadit' orientáciu na výkon vo vyučovacej komunikácii. Známkovaním udelúuú gratifikáciu, vyústúujúcu (aj ked's vel'mi rozdielnou reálnou hodnotou) do absolvovania školy. Na druhej strane dosahovanie dobrých výkonov $v$ škole a hodnotenie týchto výkonov sa uskutočňuje takmer vždy individuálne, takže žiaci sú vystavovaní navzájom do konkurenčného vzt́ahu. Lebo tzv. dobrí žiaci môžu jestvovat iba vtedy, ak súčasne jestvujú i „zlí“ alebo „slabší“ žiaci.

Učitelia sú síce vystavovaní tlaku prebrat' určitú látku, dodržiavat' pracovnú disciplínu, pravidelne hodnotit' a klasifikovat žiakov a pod., ale pri konkrétnom plnení svojich úloh získavajú určité (z času na čas meniace sa) stupne vol'nosti. Učitel' môže sám určit' formu spracovávania preberanej témy, sám si môže zvolit spôsob „oslovovania“ svojich žiakov (vyučovací štýl), sám volí prísnejší alebo menej prísny spôsob hodnotenia a klasifikácie žiakov. Vyučujúci majú teda pri plnení svojich inštitucionalizovaných úloh určitý priestor, v ktorom môžu individuálne postupovat'. Tým získavajú aj možnost' formovania svojej vlastnej, s nikým nezamenitel'nej identity počas vyučovania. Táto skutočnost' je žiakom všeobecne známa. Dobre vedia, aký je učitel' $x$ a aká je učitel'ka $y$, vedia, čo si u ktorého $z$ nich môžu dovolit', čo je u ktorého prísne zakázané, alebo naopak, na čom si ktorý z nich zakladá. Vedia, že spôsob reprodukcie učiva, ktorý je u jedného učitel'a hodnotený pozitívne, u druhého je považovaný za nedostatočný. Možno povedat', že žiaci získavajú poznatky o l'ud'och prostredníctvom poznávania svojich učitelov. Žiaci si uvedomujú, že nestačí byt' všeobecne dobrými žiakmi, ale že je nevyhnutné plnit' aj špeciálne požiadavky jednotlivých vyučujúcich. Pohybujú sa tak v sieti čiastočne dlhodobých, čiastočne krátkodobých požiadaviek na vlastné správanie. Tieto požiadavky majú všetky jednu spoločnú vlastnost', ktorá spočiva v prezentovaní týchto požiadaviek prostredníctvom moci ${ }^{8}$, pričom

8 Pozoruhodnú analýzu moci školy uverejnil Ondrej Kaščák (2006). 
odmietanie požiadaviek býva väčšinou sankcionované ako porušovanie pravidiel.

Žiaci sú konfrontovaní s mnohými požiadavkami, ktoré jednoducho nemôžu negovat́. Majú však aj svoje vlastné požiadavky, motívy a zámery, ktoré nie sú vždy konformné $s$ týmito požiadavkami. $K$ týmto požiadavkám patrí aj úsilie formovat' vlastnú identitu, uskutočňovat' predstavu o vlastnej osobnosti vo vyučovacej komunikácii. Lebo žiak, ktorý sa riadi výlučne požiadavkami toho-ktorého vyučujúceho, by sa správal automatizovane, bez známok osobnej identity.

Interakcionistickým analýzam by sme mohli vytýkat' isté opomínanie o b s a h u interakcie, kde otázky obsahu vzdelávania ostali akoby stranou. Otvorenou zostáva otázka, aký je význam získavania nových poznatkov, zaoberania sa poznatkami prírodných i spoločenských vied, historickými i politickými udalostami z hl'adiska subjektívneho vývoja a utvárania identity žiaka, ako súčasti procesu socializácie. Napriek tomu však hodnotíme teórie interakcie ako vel'ký prínos pre teóriu socializácie, kedže ju obohatila o riešenie otázok deviácie a normality. Teórie interakcie dokázali jedinečnost́ a neopakovatel'nost' procesu socializácie jednotlivca práve prostredníctvom teórie identity, a tým aj jedinečnost' subjektu a zamedzili nereálnym idealistickým špekuláciám. Súčasne sme svedkami aj znovuobjavovania a novej interpretácie základných kategórií symbolického interakcionizmu z pohladu „znovuobjaveného makrosociologického obsahu“ (Joas, 1991, s. 145).

V tomto príspevku zostáva vel'a nedopovedaného. Je to otázka utvárania identity žiakov, štítkovanie (labeling). V škole, ktorého sme svedkami skoro každodenne, a osobitne "tajný učebný plán“, ako i otázky konformity správania. Uvedené problémy by si však zaslúžili osobitnú štúdiu.

Zmienime sa aspoň stručne o otázkach identity, ktorá úzko súvisí i s módnou autoreguláciou, resp. mohli by sme povedat', že tzv. autoreguláciu podmieňuje. Ked' je ciel'om autoregulácie naučit žiakov ako vziat' zodpovednost' za svoje učenie do vlastných rúk, čo im dáva väčšie možnosti obstát na celoživotnej ceste, bez vytvárania rovnováhy medzi personálnou a sociálnou identitou, bez vzniku identity „môjho ja“ asi nemožno hovorit' o autoregulácii.

\section{INTERAKCIA A IDENTITA}

Tvorba a modifikácia identity je z hladiska interakcionistických teórií úzko spätá s každodennou komunikáciou. Otázkou však je, čo rozumieme v tejto súvislosti pod identitou? G. H. Mead $(1968,179$ - 182) rozumie pod identitou schopnost' jednotlivca reflektovat' samého seba a stat' sa sám sebe objektom. Zjednodušene povedané - schopnost' utvorit' si obraz samého seba. Mead uvádza, že izolovaný jednotlivec nie je schopný dospiet' k takejto reflexii samého seba. Identita vzniká iba vtedy, ak sa môže jednotlivec $v$ procese komunikácie (interakcie) vidiet́ očami druhého a utvárat' si obraz o sebe takýmto spôsobom. Proces interakcie je teda základným spoločenským predpokladom, aby identita vôbec mohla vzniknút. Táto identita je v podstate spoločenskou štruktúrou a vyrastá zo spoločenskej skúsenosti (Mead, 1968, 182). Túto predstavu prevzal i Goffman a rozvinul podstatným spôsobom. Podla Goffmana (1967) možno rozoznat pri očakávaniach, ktorým je subjekt vystavený pri sebareprezentácii dve dimenzie:

V línii času disponuje indivíduum vlastnou biografiou, ktorej interpretáciu subjektom možno označit' ako personálnu identitu.

V aktuálnej konkrétnej situácii je jednotlivec spojený väzbami v rôznych skupinových a rolových štruktúrach. Ich subjektívna interpretácia predstavuje sociálnu identitu. Z vytvárania rovnováhy medzi personálnou a sociálnou identitou vzniká identita môjho ja.

Habermas tento proces popisuje nasledovne: „Osobná identita nachádza svoj výraz v jedinečnej a s nikým nezamenitel'nej biografii, sociálna identita v príslušnosti jednej a tej istej osoby k rôznym, často nekompatibilným vztáahovým skupinám. Kým osobná identita je garantovaná asi ako kontinuita "ja" v priebehu meniacich sa situácií v živote, sociálna identita zachováva jednotu v mnohorakosti rôznych systémoch rol, ktoré treba "vediet" (ovládat') súčasne. Obe „identity" možno pojat ako istú "syntézu“, ktorá sa rozprestiera v dôsledku pomerov v dimenzii sociálneho času (životné udalosti), resp. 
$v$ dôsledku mnohorakosti súčasne prebiehajúcich očakávaní v dimenzii sociálneho priestoru (rol). Jaidentita môže byt' potom chápaná ako rovnováha medzi zachovávaním oboch identít, osobnej a sociálnej“ (Habermas, 1973, 131).

Identita „ja“ sa takto popisuje ako rovnováha, ku ktorej treba dospiet́ v každej interakcii. V rovine sociálnej identity sa od jednotlivca vyžaduje, aby sa orientoval na normované očakávania správania. Konajúci má byt takým, ako všetci ostatní. $V$ rovine personálnej identity sa od jednotlivca vyžaduje, aby bol s nikým nezamenitel'ný a jedinečný, má byt' takým, ako nikto iný. Ten, kto $v$ jednom alebo $v$ druhom smere príliš pol'aví, sa sám vylúči z komunikovania. Pokladá sa za podivné, ak vôbec nenaplní sociálne očakávania a pokladá sa za „zvecnenie“, ak sa jednotlivec orientuje výlučne na sociálne očakávania. Schopný komunikácie je iba ten jednotlivec, ktorý dokáže v každej situácii stále znova a znova svoju identitu obhájit' práve na pozadí príslušného sociálneho očakávania. Tento výkon je častou procesu, $v$ ktorom dochádza $\mathrm{k}$ sebareflexii subjektu. Identita môjho ja je teda procesom neustále nového výkonu $v$ interakcii.

Z hl'adiska teórie socializácie má vel'ký význam skutočnost', že proces vývoja osobnosti je tu ponímaný ako jednota zospoločenštenia a individualizácie. Tým, že jednotlivec si osvojuje reflexívnym spôsobom symboly reči, hodnoty a normy svojho sociálneho okolia, stáva sa členom spoločnosti schopným sociálneho správania. Súčasne sa ale stáva i jedinečným, neopakovatel'ným indivíduom. Pretože takto nadobudnutú identitu treba vždy znova získavat' v interakčnom procese, dostáva sa "do hry" aj biografická dimenzia - rané detstvo, rodičia, rodina, š k o I a, štúdium, výdaj a ženba a pod., ktoré predstavujú sled nadobúdania skúseností, v priebehu ktorých dochádza k novej interpretácii vlastnej identity a jej d’alšiemu rozvoju.

Ked'že identita predstavuje neustále nové výkony v každodennom živote, vyžaduje od subjektu, aby bol schopný takéto výkony podávat' a zvládat'. K tomu patria predovšetkým jazykové schopnosti, kedže väčšina komunikačných procesov sa uskutočňuje prostredníctvom jazyka ako média. Diferencované ovládanie tohto systému symbolov je preto o to dôležitejšie, o čo náročnejšie sú požiadavky na udržanie interakčnej rovnováhy. Významná je i požiadavka pohl'adu na sociálne okolie perspektívou svojho náprotivku, komunikačného partnera. Pritom je dôležité vžívat' sa do jeho pocitov, potrieb, jeho spôsobu nazerania na svet. Takáto schopnost' je empatia.

Popri jazykových schopnostiach a empatii je treba nadobudnút d’alšie „kvalifikácie“, aby mohol jednotlivec $v$ procese interakcie adekvátne a sebavedome konat. $V$ literatúre sa hovorí o frustračnej tolerancii a rolovej dištancii. Ich osvojenie predstavuje podmienku zachovania vlastnej identity aj v tažkých podmienkach. Tieto schopnosti majú svoju kognitívnu i efektívnu stránku a bývajú označované ako interakcionistická „základná kvalifikácia rolového konania“ (Habermas, 1973, 118 194).

Habermas formuluje tri rôzne roviny, ktoré predstavujú podla neho východiská štruktúry interakcie:

1. Medzi rolovým očakávaním a potrebami subjektu nejestvuje spravidla súlad. Vel'a rol dovol'uje svojmu aktérovi (nositel'ovi roly) iba obmedzené uspokojenie, napriek tomu však musí $v$ interakcii pokračovat'. Psychickým ekvivalentom je tu frustračná tolerancia, ktorá vystupuje ako reakcia na to, že rolové očakávania a pozičné potreby sa u jednotlivca nekryjú. Takáto koncepcia je $v$ rozpore $s$ Parsonsovou tézou, podla ktorej $v$ ideálnom prípade rolové konanie uspokojuje potreby oboch (komunikačných) partnerov tým, že naplňajú svoje roly. Habermas sa domnieva, že „....vo všetkých doposial' známych spoločnostiach jestvoval fundamentálny nesúlad medzi masou interpretovaných požiadaviek a spoločnostou licencovaných požiadaviek ako rolí inštitucionalizovaných hodnotových orientácií" (Habermas, tamtiež, 125). Rozsah, v ktorom sa nachádza čast' interakcie, resp. $v$ akom uspokojuje požiadavky druhého, dovol'uje usudzovat' na stupeň represie v príslušnej inštitúcii spoločnosti;

2. Medzi rolovým očakávaním a skutočným správaním (interpretáciou roly) nejestvuje totožnost', ale vztah zásadného napätia. Rolové očakávania nie sú nikdy definitívne a presne stanovené, 
takže rolové konanie si vyžaduje neustále interpretáciu očakávaní. To korešponduje s požiadavkou konajúceho subjektu, aby sa mohol pri preberaní konkrétnej roly „....súčasne predstavovat' ako nezastupitel'né indivíduum" (Habermas, tamtiež, 26). Z toho vyplýva požiadavka na subjekt, aby hladal a nachádzal v difúznych situáciách (ktoré Habermas nazýva rolovou dvojakostou, ambiguitúciou - Rollenambiguität) skôr adekvátny vztáah medzi preberaním rol a navrhovaním, ponúkaním rol. Táto schopnost', t. j. znášat' a zvládat' nejasnosti a ambivalenciu, a napriek tomu zachovat' si schopnost' konat', sa nazýva ambiguitová tolerancia a je považovaná za jednu z najdôležitejších „kvalifikačných“ predpokladov rolového konania. Habermas hovorí d'alej o tom, že „....úplná a dokonalá definícia roly, ktorá by prejudikovala totožnú interpretáciu všetkých zúčastnených (na interakcii) je možná iba v zvecnenom vzt́ahu, vylučujúcom sebareprezentáciu" (Habermas, tamtiež, 126). Rozsah, v ktorom sa interakcia približuje takejto situácii, dovol'uje posudzovat' stupeň rigidity systému rol v spoločnosti;

3. Napokon je treba sa kriticky vyjadrit' $\mathrm{k}$ tomu, že štrukturálno-funkcionalistická teória rol vychádza z predpokladu, že platné spoločenské normy a subjektívne osvojené hodnoty sú vo vel'kej miere totožné. Podla tejto teórie inštitucionalizovaná hodnotová orientácia (rola) zodpovedá internalizovanej hodnote (ako motív), a to tak, že platné normy s vel'kou pravdepodobnost́ou sa budú aj skutočne plnit'. Túto tézu nazýva Habermas teorémou konformity a súčasne ju ostro kritizuje. Správanie, ktoré je konformné k normám, nie je jednoduchou reflexiou dopredu daných očakávaní, ovel'a skôr závisí takéto správanie od stupňa a spôsobu internalizácie, ako sa subjekt správa k svojej vlastnej role. Subjekty teda principiálne pristupujú k role v istom reflektovanom vzt́ahu. Schopnost' spojená s takýmto prístupom k role je nazývaná rolový odstup, (rolová dištancia, nem. Rollendistanz). Ked' subjekty nemôžu alebo nesmú v interakcii tento rolový odstup realizovat', zaznamenávame deficit autonómie subjektu.

Uvedené teórie majú mimoriadny význam pre analýzu procesu socializácie v škole. $V$ strede sa ocitá kategória identity "ja“", pomocou ktorej sa opisuje sociálne ukotvenie subjektívnych schopností v sociálnej oblasti. Je to individualita, ktorá sa vytvorila v biografickej dimenzii života a ktorá vstupuje do súčasnej sociálnej roly aktívne konajúceho subjektu. Teória interakcie spĺña tak hned' dve dôležité funkcie:

1. dokáže vysvetlit' socializáciu ako jednotu zospoločenštenia a súčasne aj individualizácie;

2. predstavuje subjekt ako aktívne konajúci a spoluformujúci svoj vlastný vývin.

Ak chápeme takýmto spôsobom identitu „ja“, ako i s ňou spojenú základnú sociálnu kvalifikáciu ako najvyšší výchovný ciel', môže znamenat' prínos teórie interakcie zásadný obrat aj v teórii socializácie, no najmä jej vstup do pedagogiky. Prostredníctvom tohto normatívneho komponentu sa možno pýtat', či sú v súčasnosti prebiehajúcej p e d a g o g i c k e j interakcii podmienky pre vývin identity priaznivé alebo nepriaznivé. Môžeme sa pýtat', ktoré štruktúry systému rol bránia alebo stažujú utváranie identity návštevníkov škôl (žiakov, študentov, detí a mládeže).

\section{MIESTO ZÁVERU: UTVÁRANIE IDENTITY ŽIAKOV}

Príspevok si nekladie za úlohu navrhovat', ako pracovat' s poznatkami, ktoré sú jeho obsahom. Majú prispiet' $\mathrm{k}$ integrácii pedagogiky s d'alšími spoločenskými vedami a jej transdisciplinarite. Preto ústi príspevok do problematiky utvárania identity žiakov, ako významnej súčasti výchovy a vzdelávania. Škola ako inštitúcia stavia svojich klientov (žiakov) do situácie, ktorá je už vopred štruktúrovaná, hierarchicky usporiadaná a ktorá je určovaná problematikou výkonov. Od žiakov sa po mnohé roky vyžaduje, aby sa vo vnútri takejto komunikačnej štruktúry pohybovali adekvátne, aby mohli v tomto kontexte utvárat' svoju identitu. Na otázku, aké vplyvy je možné zaznamenat' na utváranie osobnosti mladého človeka, dávame do pozornosti interakcionistickú analýzu, ktorá upozorňuje, že i pri inštitucionálnych požiadavkách na správanie účastníkov interakčného procesu jestvuje interpretácia 
rol, ktorá sa stáva súčast'ou výchovy. Aj žiaci disponujú istým priestorom pre role-making. Výskumy súčasne poukazujú na to, že žiaden žiak nie je schopný napriek uvedenému priestoru, ktorým disponuje pre role-making utvárat' si vlastnú identitu bez toho, aby sa vyrovnal a „spracoval“ aj problematiku podávania svojich výkonov. Úspech a zlyhanie sú zo strany školy ako inštitúcie tak masívne zdôrazňované a používané, že nikto zo žiakov nemôže nimi zostat́ nedotknutý, či už úspechom alebo zlyhaním. Samozrejme, význam úspechu alebo aj zlyhania môže byt́ pre jednotlivcov rôzny z hladiska významu pre ich identitu. Interakcionistická teória socializácie vidí tento proces $v$ škole $v$ podobe procesu normovania a individualizácie, lebo všetci žiaci sa s touto témou musia vyrovnat' a vo svojej identite zaujat' k nej stanovisko, aj ked's rozdielnym výsledkom a rozdielnym riešením. Žiaci, ktorých doposial' v škole stíhal iba neúspech, kritérium výkonu a úspechu spracúvajú ináč ako žiaci, ktorí boli doposial'v škole väčšinou úspešní. Prví z nich prežívajú školu ako donucovaciu inštitúciu, učitelov ako svojvol'ne jednajúcich. Učitel'ov vykresl'ujú ako ludí, ktorí potláčajú ich nezávislost', samostatnost' a rozbíjajú ich vlastnú identitu. Niektorí z nich sa často považujú za nespôsobilých a zlyhávajúcich a robia si často starosti o svoju budúcnost' a zamestnanie. Nazdávajú sa, že sa málo a nedostatočne riadili pokynmi a prianím učitel'ov. Len čast' z nich kladie bezvýhradne vinu škole a učitel'om, pričom sa nazdávajú, že oni sa dostatočne snažili, ale boli nespravodlivo vydaní napospas vyučujúcim. $V$ oboch prípadoch však preberajú inštitucionálnu definíciu neúspechu a zlyhania na seba a vytvárajú si všeobecnú teóriu, ktorá má ich zlyhanie vysvetlit' a súčasne chránit' ich identitu. Pritom však legitimitu princípu výkonu, hodnotenia a výberu obyčajne nikto nespochybňuje, aj ked' sami zlyhali.

Objektívna pozícia žiaka vo výkonovej hierarchii významne ovplyvňuje problémy jeho identity. Úspech, resp. zlyhanie sa stáva pre väčšinu žiakov centrálnym problémom, s ktorým sa musia vyrovnat' a spracovat ho vlastnou interpretáciou. Kým pre „slabších“ žiakov sa stáva zlyhávanie istým ohrozením ich identity, pre „dobrých“ žiakov je úspech, naopak, zdrojom sebavedomia a sebaistoty. To sa zretel'ne prejavuje i vo vyučovacej komunikácii. Výkonnostne úspešnejší žiaci ovládajú klaviatúru prispôsobovania sa a sebaprezentácie ovel'a lepšie. Na báze rolového odstupu, tzv. rolovej dištancie sú v stave úspešne komunikovat' aj v hierarchicky usporiadanej skupine, alebo v odcudzených, tažkých podmienkach, kde dokážu relatívne l'ahko spracovat' požiadavky, ktoré sú na nich kladené. Naopak, neúspešní a zlyhávajúci žiaci dokážu spracovávat protirečenie medzi svojimi osobnými aktuálnymi požiadavkami a požiadavkami školy len vel'mi nedostatočne alebo vôbec nie. Pre ich správanie je typická nie dištancovaná interpretácia roly, ale skôr demonštratívne odmietanie preberania roly. $v$ takom prípade bude iste otázne hovorit' o autoregulácii. Porozumenie týmto procesom poskytuje lepšie predpoklady pre vztah socializácie a výchovy.

\section{LITERATÚRA}

Alexander, J. \& Thompson, K. (2008). A Contemporary Introduction to Sociology: Culture and Society in Transition. Ohio: Boulder, Paradigm Publishers.

Alijevová, D. et al. (2012). Príspevok Alfreda Schütza k sociologickej teórii. Praha: Slon.

Bühlerová, Ch. (1928). Kindheit und Jugend. Leipzig: S. Hirzel.

Beck, U. (1986). Risikogesellschaft. Auf dem Weg in eine andere Moderne. Frankfurt am M.: Suhrkamp.

Bell, D. (1985). Die nachindustrielle Gesellschaft. Frankfurt/ Main, New York: Campus.

Bowles, S. \& Gintis, H. (1978). Pädagogik und die Wiedersprüche der Ökonomie. Das Beispiel USA, Frankfurt am Main: Suhrkamp.

Brumlik, M., Holtappels, H. G.: (1987): Mead und die Handlungsperspektive schulischer Akteure interaktionistische Beiträge zur Schultheorie, in: K.-J. Tillmann (Hrsg.), Schultheorien, s. 89-103. Hamburg: Berghmann u. Helbig 1987. 2. vydanie 1993.

Buraj, I. (2000) Foucault a moc. Bratislava: UK. 
Dreeben, R. (1980). Was wir in der Schule lernen, Frankfurt/Main: Suhrkamp.

Durkheim, E. (1977). Über die Teilung der sozialen Arbeit. Frankfurt am Main: Suhrkamp.

Fend, H. (1973). Sozialisationsefekte unterschiedlicher Schulformen, In Zeitschrift für Pädagogik, 6(1). Foucault, M. (1969). L'archéologie du savoir. Paris: Gallimard.

Freud, S. (1969). Vorlesungen zur Einführung in die Psychoanalyse (1916-1918), In Gsammelte Werke Bd. X, Metapsychologische Ergänzungen zur Traumlehre (1917) (s. 265-303), Frankfurt am Main: Fischer.

Fromm, E. (1991). Die Furcht vor der Freiheit, München: Deutschen Taschenbuch Verlag.

Geertz, C. (1973). The Interpretation of Culture. New York: Basic Books.

Goffman, E. (1967). Stigma. Über Techniken der Beweltigung beschedigter Identität. Frankfurt am Main: Suhrkamp.

Habermas, J. (1973). Kultur und Kritik. Verstreute Aufsätze. Frankfurt am Main: Suhrkamp.

Habermas, J. (1973). Stichworte zu einer Theorie der Sozialisation. In J. Habermas, Kultur und Kritik (s. 118-194), Frankfurt am Main: Suhrkamp.

Heitmeyer, W. \& Hagan, J. (2003). International Handbook of Violence Research. Springer.

Heitmeyer, W. \& Olk, Th. (1990). Individualisierung von Jugend. Weinheim, München: Juventa.

Holtappels, H. G. (1987). Schulprobleme und abweichendes Verhalten aus der Schülerperspektive. Bochum: Schallwig Verlag.

Hurrelmann, K. \& Ulich, D. (Hrsg.) (1991). Neues Hanbuch der Sozialisationsforschung. Weinheim, Basel: Beltz.

Joas, H. (1991). Rollen- und Interaktionstheorien in der Sozialisationsforschung, In K., Hurrelmann, D. Ulich (Hrsg.): Neues Hanbuch der Sozialisationsforschung (s. 137-152), Weinheim, Basel: Beltz.

Jurovský, A. (1969). Socializačné činitele v duševnom živote súčasnej mládeže. Sociológia, 4(1), 305323.

Kaščák, O. (2006). Moc školy. O formatívnej sile organizácie. Bratislava: VEDA.

Maslow, A. H. (2001). Ku psychológii bytia. Modra: Persona.

Mead, G. H. (1968). Geist, Identität und Gesellschaft, Frankfurt/Main: Suhrkamp.

Mohr, R., Saltzwedel, J., Schmitter, E. \& Schreiber, M. (2001). Die unverschleierte Würde des Westens. Spiegel, 52, 50-66.

Ondrejkovič, P. (1995). Úvod do sociológie výchovy. Teoretické základy sociológie výchovy a mládeže. Bratislava: Veda, SAV.

Ondrejkovič, P. (1997). Socializácia mládeže ako východisková kategória sociológie výchovy a sociológie mládeže. Bratislava: Veda.

Ondrejkovič, P. (2002). Globalizácia a individualizácia mládeže. Bratislava: Veda.

Ondrejkovič, P. (2004). Socializácia v sociológii výchovy. Bratislava: SAV VEDA.

Ondrejkovič, P. \& Majerčíková, J. (2012). Vysvetlenie, porozumenie a interpretácia $v$ spoločenskovednom výskume. Bratislava: SAV VEDA.

Parsons, T. (1968). Sozialstruktur und Persönlichkeit. Frankfurt am Main: Europäische Verlagsanstalt. 
Plichtová J. (2001). Diskurzívne verzus tradičné chápanie mysle. In Harré, R., Gillet G. R., Diskurz a mysel' (s. 7-27). Bratislava: Iris.

Prokop, J. (1998) Socializace ve škole In: Kapitoly z pedagogiky, Praha: Pedagogická fakulta Univerzity Karlovy, s. 65-95.

Schütz, A. (1981). Theorie der Lebensformen. Frankfurt am Main: Suhrkamp.

Spitz, R. (1967). Von Säugling zum Kleinkind. Stuttgart: Enke.

Stern, W. (1930). Psychologie der frühen Kindheit. Leipzig: Verlag Qulelle \& Meyer.

Strouhal, M. (2010). K morálním a pedagogickým aspektům Durkheimova pojetí socializace. In: Pedagogický časopis/Journal of Pedagogy 1/2010, s. 25-48.

Strouhal, M. (2013). O různých podobách autority. Př́spěvek k filosofii výchovy. In Zahatňanská, M. Dupkalová, M. (eds.) Vybrané kapitoly z teórie výchovy. Prešov: UNIPO, s. 67-75.

Tillmann, K. J. (Hrsg.) (1987). Schultheorien. Hamburg: Bergmann und Helbig.

Tillmann, Klaus-Jürgen (1976). Unterricht als soziales Erfahrungsfeld. Frankfurt am Main: VS Verlag für Sozialwissenschaften.

Zinnecker, J. (1985). Jugend der Gegenwart - Begin oder Ende einer historischen Epoche? In D. Baccke, W. Heitmeyer (Hrsg.). Neue Wiedersprüche - Jugendliche in den achtziger Jahren (s. 24-45). Weinheim, München.

\section{Autor}

Prof. PhDr. Peter Ondrejkovič, DrSc., Centrum výzkumu, Fakulta humanitních studií, Univerzita Tomáše Bati ve Zlíně, nám. T. G. Masaryka 1279, 76001 Zlín, e-mail: ondrejkovic@fhs.utb.cz

\section{The process of socialization and education in school}

Abstract: Becoming a social being is not just a matter of education; it is a process of socialization, "learning in social conditions", and the process of formation and development of personality in the interdependence of a socially mediated social and physical environment. A theory of socialization at school must explain how social reproduction is associated with the development of one's personality and also must explain how they can work together in the critical development of entity and societal changes. It is an important part of education and is responsible for the identity formation of students. Without creating an identity "of me" it is not possible to speak about self-regulation.

Keywords: socialization, upbringing, education, identity, interactionism 